\begin{tabular}{|c|l|}
\hline Title & $\begin{array}{l}\text { Photosynthesis and nitrogen al location in needles in the sun and shade crowns of hybrid larch saplings: effect of } \\
\text { nitrogen application }\end{array}$ \\
\hline Author(s) & Mao, Q. Z.; W atanabe, M.; Imori, M.; Kim, Y. S.; Kita, K.; Koike, T. \\
\hline Citation & $\begin{array}{l}\text { Photosynthetica, 50(3), 422-428 } \\
\text { https://doi.org/40.1007/311099-012-0049-z }\end{array}$ \\
\hline Issue Date & 2012-09 \\
\hline Doc URL & http://hdl.handle.net/2115/50087 \\
\hline Rights & The final publication is available at www.springerlink.com \\
\hline Type & article (author version) \\
\hline File Information & Pho50-3_422-428.pdf \\
\hline
\end{tabular}

Instructions for use 


\title{
Photosynthesis and nitrogen allocation in needles in the sun and shade crowns of hybrid larch saplings: effect of nitrogen application
}

\author{
Q.Z. MAO*, M. WATANABE*, M. IMORI*, Y.S. KIM*, K. KITA* , and T. KOIKE ${ }^{*++}$ \\ Silviculture and Forest Ecological Studies, Hokkaido University, Sapporo, Hokkaido - 0608589, Japan * \\ Forestry Research Institute, Hokkaido Research Organization, Bibai-0790198, Japan ** \\ Present address of Y.S. Kim: Division of Forest Conservation, KoreaForest Research Institute, Seoul-130712, Republic \\ of Korea
}

\begin{abstract}
We studied the effects of applying $50 \mathrm{~kg}(\mathrm{~N}) \mathrm{ha}^{-1}$ year $^{-1}$ of nitrogen $(\mathrm{N})$ on needle photosynthesis, $\mathrm{N}$ allocation and nutrient content in the sun and shade crowns of the hybrid larch $\mathrm{F}_{1}$ (Larix gmelinii var. japonica $\times$ L. kaempferi). The light-saturated net photosynthetic rate $\left(P_{\mathrm{Nmax}}\right)$ was not significantly affected by $\mathrm{N}$ application or crown position, although the contents of $\mathrm{N}, \mathrm{P}, \mathrm{K}$, and chlorophyll (Chl), and the maximum rates of carboxylation and electron transport were lower in needles of the shade crown than of the sun crown. This difference was mainly due to an increase in the intercellular $\mathrm{CO}_{2}$ concentration $\left(C_{\mathrm{i}}\right)$ in the needles of the shade crown. Analysis of $\mathrm{N}$ allocation in photosynthetic systems revealed that more $\mathrm{N}$ was allocated to functions related to electron transport and ribulose-1,5-bisphosphate $(\mathrm{RuBP})$ regeneration in needles of the shade crown. $\mathrm{N}$ allocation in needles of the hybrid larch $\mathrm{F}_{1}$ was regulated mainly by the light conditions, rather than by $\mathrm{N}$ application.
\end{abstract}

Additional key words: foliar nutrient; hybrid larch; nitrogen deposition; sun- and shade needles.

\section{Introduction}

To maintain a high growth rate of trees, photosynthesis should take place throughout the entire crown, with efficient use of N resources (Š́esták 1985, Matyssek et al. 2008). This is because $\mathrm{N}$ is believed to be a primary limiting resource in northern forests (Schulze et al. 2005, Braun et al. 2010, Anten and During 2011). It is therefore important to know the $\mathrm{N}$ allocation to the crown according to the environment (Marek et al. 2002, Lambers et al. 2008).

Recently, we develop a new hybrid larch species $\mathrm{F}_{1}$ (Larix gmelinii var. japonica $\times$ L. kaempferi). It is a fast growing, light-demanding species and has good tolerance against both biotic and abiotic stresses (Ryu et al. 2009). It is recognized as one of the most promising species for moderating atmospheric $\mathrm{CO}_{2}$ throughout northeast Asia because of its high storage capacity of carbon in the stem with high specific gravity (Koike et al. 2000, Qu et al. 2004). The response of the hybrid larch to nutrient availability is not well known, in particular the allocation traits of $\mathrm{N}$ (Koike 2009).

Received 17 September 2011, accepted 2 May 2012.

${ }^{+}$Corresponding author; phone: +81-11-706-3854, fax: +81-11-706-2517, e-mail: tkoike@ for.agr.hokudai.ac.jp

Abbreviations: $C_{\mathrm{a}}$ - external $\mathrm{CO}_{2}$ concentration; $C_{\mathrm{i}}-$ intercellular $\mathrm{CO}_{2}$ concentration; Ca - calcium; Chl - chlorophyll; $g_{\mathrm{s}}-\mathrm{stomatal}$ conductance of water vapor; $J_{\max }-$ maximum rate of electron transport; $\mathrm{K}$ - potassium; $K_{\mathrm{c}}-$ value of Rubisco Michaelis constants for $\mathrm{CO}_{2} ; K_{\mathrm{o}}$ - value of Rubisco Michaelis constants for $\mathrm{O}_{2}$; LHCP - light-harvesting chlorophyll complex protein; LMA - leaf mass per area; $\mathrm{Mg}$ - magnesium; $\mathrm{N}$ - nitrogen; $N_{1}$ - nitrogen allocated in light-harvesting chlorophyll complex protein and photosystems; $N_{2}-$ nitrogen allocated in bioenergetics (electron carriers except for photosystems, coupling factor and Calvin cycle enzymes except for Rubisco); $N_{3}$ - nitrogen allocated in Rubisco; $N_{4}$ - nitrogen allocated in other components in needle; $N_{\mathrm{m}}-\mathrm{N}$ content per unit leaf mass; $\mathrm{P}-$ phosphorus; $P_{\max }-$ net assimilation rate at $1,700 \mu \mathrm{mol} \mathrm{mol}{ }^{-1} \mathrm{CO}_{2}, P_{\mathrm{N}}-$ net assimilation rate; $P_{\mathrm{Nmax}}-$ light-saturated net photosynthetic rate; PNUE - photosynthetic nitrogen use efficiency; PPF - photosynthetic photon flux; $V_{\text {cmax }}-$ maximum rate of carboxylation; $V_{\mathrm{cr}}$ - the specific activity of Rubisco, $\Gamma^{*}-\mathrm{CO}_{2}$ compensation point in the absence of dark respiration.

Acknowledgements: We thank Prof. K. Hikosaka, Dr. N.P.R. Anten and Prof. Ü. Niinemtes for their encouragment in this study. Thanks are also due to Dr. Anthony Garrett of Scitext Cambridge, U.K. for linguistic comments. We acknowledge financial support in part via a Grant-in-Aid from the Japan Society for the Promotion of Science through Scientific Research on Innovative Areas (to T. Koike). Research Fellowships for Young Scientists program (to M. Watanabe and Y.S. Kim), and Young Scientists B (to M. Watanabe) and also a project study grant from Development of Mitigation and Adaptation Techniques to Global Warming in the Sectors of Agriculture, Forestry, and Fisheries (to K. Kita). 
We usually plant larch seedlings at a fairly high density in plantations for high quality timber. As a result, after several years, the crown of these larches will suffer from self-shading or between-tree shading (Kuuluvainen and Pukkala 1989, Marek et al. 2002). N is allocated within the foliage of the crown according to the light conditions in each part of the plant (Hirose and Werger 1987, Hirose et al. 1988, Niinemets 1997, Schulze et al. 2005). More $\mathrm{N}$ is generally allocated to foliage in the upper sun crown than to the lower shade crown (Rosati et al. 2000, Lambers et al. 2008).

Nitrogen allocation between foliage was also influenced by the incident light conditions at the forest floor. Kitaoka and Koike (2004) observed $\mathrm{N}$ allocation between photosynthetic systems in the leaves of four deciduous broad-leaved tree species regenerated in the forest floor. $\mathrm{N}$ allocation changed according to the changing light conditions during the growing season. There was also a clear difference in $\mathrm{N}$ allocation traits depending on the specific leaf phenology of the tree species.

Atmospheric $\mathrm{N}$ deposition has recently been increasing rapidly, especially in eastern Asia, and this trend is expected to continue (Galloway et al. 2004, Magnani et al. 2007). Previous studies of how the N supply affects responses to irradiance have concentrated on herbaceous plants, and there is little information on tree species (Kitaoka et al. 2009). The main effect of increased $\mathrm{N}$ availability is an increase in the photosynthetic capacity of partially shaded leaves, although there is no increase in the maximum capacity of leaves exposed to strong light (DeJong et al. 1989). Posch et al. (2008) found that application of $\mathrm{N}$ fertilizer affected mainly the biochemistry and light-use physiology of lower- and mid-canopy needles of Pinus radiata, increasing the amount of $\mathrm{Chl}$ and hence the amount of the harvested light. We therefore expect increasing $\mathrm{N}$ deposition to affect $\mathrm{N}$ allocation in shaded foliage. However, it is not known whether deciduous conifers respond differently.

How does the hybrid larch deal with changes in irradiation by means of efficient $\mathrm{N}$ allocation between differing positions within the crown, and within needles? A better understanding of $\mathrm{N}$ allocation to photosynthetic systems is needed. In the present study we compared photosynthetic traits in lower- and upper-crown needles of hybrid larch saplings grown with and without $\mathrm{N}$ application, to assess the photosynthetic acclimation of needles in relation to $\mathrm{N}$ allocation. We also discuss the interaction between $\mathrm{N}$ application, and the differing conditions of irradiation experienced by different crown positions, in photosynthesis of the hybrid larch.

\section{Materials and methods}

Experimental site and plants: On $21^{\text {st }}$ May 2008, planting stocks of 3-year-old clonal seedlings of the hybrid larch $\mathrm{F}_{1}$ (sp. "Gream" as a nickname; hereafter 'hybrid larch') were planted in the Sapporo Experimental Forest of Hokkaido University, Japan $\left(43.07^{\circ} \mathrm{N}, 141.38^{\circ} \mathrm{E}, 15 \mathrm{~m}\right.$ a.s.1.). The hybrid larch was originally developed by crossing female Dahurian larch (L. gmelinii var. japonica Pilg.) from the Kurile Islands and Sakhalin with male Japanese larch ( $L$. kaempferi Carr. $=$ L. leptolepis Gordon). The hybrid had tolerance not only to shoot blight disease, grazing by Redback voles and deer, but also to environmental stresses such as drought, low temperature and heavy snow (Ryu et al. 2009). Larches have two types of shoot: short shoots and long shoots (Kitaoka et al. 2000). Short shoots flush their needles once in spring, and long shoots develop needles from early July until late August. We focus on long-shoot needles because of their high photosynthetic capacity as compared with short-shoot needles (Kitaoka et al. 2000).

The soil in the nursery is classified as brown forest soil, which is common in Japan (Nakaji et al. 2002, Kayama et al. 2009). The planting density for experimental use was $4,200 \mathrm{ha}^{-1}$. The average \pm SD values of height (from soil surface to apical point) and diameter (at $3 \mathrm{~cm}$ height from soil surface) at the beginning of experiment in May 2008 were $79.6 \pm 8.5 \mathrm{~cm}$ and $0.97 \pm 0.10 \mathrm{~cm}$ in the $\mathrm{N}$-treatment plots, and $77.5 \pm 7.5 \mathrm{~cm}$ and $0.97 \pm 0.09 \mathrm{~cm}$ in the control plots.

The experimental site has a cool temperate climate, with adequate rainfall (annual rainfall was $843 \mathrm{~mm}$ in 2008 , $1,147 \mathrm{~mm}$ in 2009 and 1,325 mm in 2010; reported by Japan Meteorological Agency, 2012). The snow-free period is late April to early November. From May to October, the growing season average air temperature at the study site was $19.5^{\circ} \mathrm{C}$. Maximum and minimum temperatures from May to October were $35.2^{\circ} \mathrm{C}$ in August and $8.3^{\circ} \mathrm{C}$ in October. The monthly average photosynthetic photon flux (PPF) converted from light intensity by $\mathrm{HOBO}$ (Pendant Temperature/Light Data Logger, 64K-UA-002-64, Onset, USA) during the three years was shown in Fig. 1. The highest PPF was found in June (over $350 \mu \mathrm{mol} \mathrm{m} \mathrm{m}^{-1}$ ) and gradually decreased until October (around $170 \mu \mathrm{mol} \mathrm{m} \mathrm{m}^{-2} \mathrm{~s}^{-1}$ ).

Experimental design: We set two levels of N, 0 and $50 \mathrm{~kg}(\mathrm{~N}) \mathrm{ha}^{-1}$ year $^{-1}$, referred to as N0 and N50. The plots were replicated 3 times for each $\mathrm{N}$ level. Each plot $(4.5 \times 7.5 \mathrm{~m})$ contained 15 seedlings. The plots with and without $\mathrm{N}$ application were distributed alternately. In each growing season, ammonium nitrate solution (14 mM) was supplied by watering pot to the soil surface of the N50 plots. In 2008, N was supplied on 25 June, 11 July, 1 August, and 22 August. In 2009, N was supplied on 18 May, 27 June, 6 August, and 18 September. In 2010, N was supplied on 31 May, 7 July, 11 August and 13 September. The same amount of tap water without ammonium nitrate was supplied to the N0 plots. Kimura et al. (2009) reported the amount of atmospheric nitrogen deposition in the forest in the Kanto 


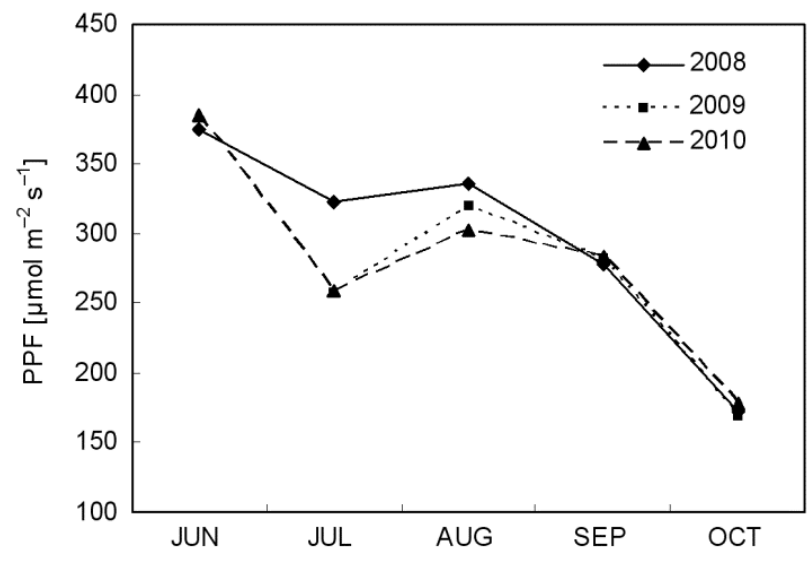

Fig. 1. Monthly average photosynthetic photon flux (PPF) during the experiment period. $n=3$.

region of Japan to be $30-50 \mathrm{~kg}(\mathrm{~N}) \mathrm{ha}^{-1}$ year $^{-1}$. Moreover, Galloway et al. (2004) assert that $\mathrm{N}$ deposition to the ground will increase; that is why we chose to administer $50 \mathrm{~kg}(\mathrm{~N}) \mathrm{ha}^{-1} \mathrm{year}^{-1}$.

Soil solution was collected from 2008 to 2010 during the growing season (10 days before and after N application) using a tension lysimeter (Dik-8390, Daiki Rika Kogyo Co., Ltd., Saitama, Japan). The pH of the soil solution was measured using a pH meter (M-12, Horiba, Kyoto, Japan). The contents of inorganic nitrogen (i.e. $\mathrm{NH}_{4}^{+}$and $\mathrm{NO}_{3}{ }^{-}$) were measured with a continuous flow type analyzer (Auto analyzer, BL-TEC, AACS-4, Osaka, Japan). Contents of potassium (K), calcium $(\mathrm{Ca})$, and magnesium $(\mathrm{Mg})$ were measured by inductively coupled plasma-atomic emission spectrometry $(I C P$ AES, IRIS, Jarrel Ash, Franklin, MA, USA).

Light environment of needles: The shade crown was defined as within $50 \mathrm{~cm}$ from the ground and $50 \mathrm{~cm}$ horizontally away from the stem, where mutual shading of lower shoots had begun in early July, 2010. The sun crown was defined as $150 \mathrm{~cm}$ high off the ground and $50 \mathrm{~cm}$ horizontally away from the stem. Light intensity at the shade- and sun-crown positions were measured (the same with above) in September after long-shoot development had ceased (Kitaoka et al. 2000).

Needle gas exchange was measured for long-shoot needles from both the shade and sun crowns from mid-September in 2010, when the needles had matured. The needles studied in both upper and lower crowns were the long-shoot needles which had emerged in early June and matured by late August (Kitaoka et al. 2000). These measurements were made in September 2010 using an open gas-exchange system (LI-6400, Li-Cor Inc., Lincoln, NE, USA) with a light-emitting diode light source (LI-6400-40). Using two or three seedlings per plot, we established the intercellular $\mathrm{CO}_{2}$ concentration $\left(C_{\mathrm{i}}\right)$-response curve for the $P_{\mathrm{N}}$ with 11 steps of external $\mathrm{CO}_{2}$ concentration $\left(C_{\mathrm{a}}\right)$. The order of the $\mathrm{C}_{\mathrm{a}}$ values during the measurement was 380, 300, 220, 140, 60, 380, 500, 800;1,100; 1,400; and 1,700 ppm (Long and Bernacchi 2003). During the measurements, the needle temperature and light PPF from light-emitting diode light source were maintained at $25.0 \pm 1.0^{\circ} \mathrm{C}$ and $1,500\left[\mu \mathrm{mol} \mathrm{m} \mathrm{m}^{-2} \mathrm{~s}^{-1}\right]$ respectively, which had been determined as the conditions maximizing the photosynthetic capacity of this species (Ryu et al. 2009). The leaf-to-air vapor pressure deficit was approximately 1.5 $\mathrm{kPa}$, reflecting ambient water vapor conditions in the experimental field.

The $P_{\mathrm{N}} / C_{\mathrm{i}}$ curve was used to estimate $P_{\mathrm{Nmax}}$ and stomatal conductance $\left(g_{\mathrm{s}}\right)$ at $380\left[\mu \mathrm{mol}\left(\mathrm{CO}_{2}\right)\right.$ mol $\left.{ }^{-1}\right]$, the net assimilation rate at $1,700\left[\mu \mathrm{mol}\left(\mathrm{CO}_{2}\right) \mathrm{mol}^{-1}\right]\left(P_{\max }\right)$, the maximum rate of carboxylation $\left(V_{\mathrm{cmax}}\right)$, and the maximum rate of electron transport $\left(J_{\max }\right)$ (Farquhar et al. 1980, Long and Bernacchi 2003). The values of the Rubisco Michaelis constants for $\mathrm{CO}_{2}\left(K_{\mathrm{c}}\right)$ and $\mathrm{O}_{2}\left(K_{\mathrm{o}}\right)$, and the $\mathrm{CO}_{2}$ compensation point in the absence of dark respiration $\left(\Gamma^{*}\right)$, were calculated according to Bernacchi et al. (2001) based on analysis of the $P_{\mathrm{N}} / C_{\mathrm{i}}$ curve. All gas-exchange parameters were expressed on the basis of the projected needle area as measured with an image scanner (CanoScan LiDE 600F, Canon, Tokyo, Japan).

Foliar nutrients and Chl: After the gas-exchange measurements, the needles were collected and the leaf mass per area (LMA) was determined. This was calculated as the ratio of dry mass (measured after oven-drying at $60^{\circ} \mathrm{C}$ for 5 days) to the needle surface area. The leaf area was determined by a leaf image scanner as described above. The dried needles were then ground into fine powder and their $\mathrm{N}$ content was determined by the combustion method, using a NC analyzer (NC-900, Sumica-Shimadzu, Kyoto, Japan). The photosynthetic N-use efficiency (PNUE) was calculated as $P_{\text {Nmax }}$ divided by the needle $\mathrm{N}$ content. 
The needle powder samples were digested by $\mathrm{HNO}_{3}, \mathrm{HCl}$, and $\mathrm{H}_{2} \mathrm{O}_{2}$. The contents of phosphorus (P), magnesium $(\mathrm{Mg})$, and potassium $(\mathrm{K})$ in these sample solutions were determined using the ICP-AES referred to above. The fresh needle samples for $\mathrm{Chl}$ measurement were stored at $-80^{\circ} \mathrm{C}$; Chl was extracted with dimethyl sulfoxide according to the method of Barnes et al.(1992) and Shinano et al. (1996) and was quantified using a spectrophotometer (Gene spec III, Hitachi, Tokyo, Japan).

Nitrogen allocation to the photosynthetic system: The photosynthetic apparatus was divided into four parts: (1) lightharvesting Chl complex protein (LHCP) and photosystems; (2) bioenergetics (electron carriers except for photosystems, coupling factor and Calvin-cycle enzymes except for Rubisco); (3) Rubisco and (4) others; these are denoted by $N_{1}, N_{2}$, $N_{3}$ and $N_{4}$, respectively. We estimated $N_{1}$, assuming a $\mathrm{N}$ content per unit Chl content of $37.1 \mathrm{~mol} \mathrm{~mol}{ }^{-1}$ (Barnes et al. 1992), as:

$$
N_{1}(\%)=(\mathrm{Chl} \times 0.5194) / \mathrm{LMA} N_{\mathrm{m}},
$$

We estimated $N_{2}$ from gas-exchange characteristics according to the following equation (Field 1983, Takashima et al. 2004):

$$
N_{2}(\%)=J_{\max } /\left(156 \times 9.53 \mathrm{LMA} N_{\mathrm{m}}\right),
$$

where $N_{\mathrm{m}}$ denotes $\mathrm{N}$ per unit leaf mass. It is assumed here that nitrogen in bioenergetics is proportional to $J_{\max }$, where the ratio of $J_{\max }$ to the cytochrome $f$ content is $156\left[\mathrm{mmol} \mathrm{mol}^{-1} \mathrm{~s}^{-1}\right]$ (Niinemets et al. 1997), and nitrogen in bioenergetics per unit cytochrome $f$ has value $9.53\left[\mathrm{~mol} \mathrm{mmol}^{-1}\right]$. We estimated $N_{3}$ using the following equation (Niinemets et al. 1999, Tissue and Lewis 2010):

$$
N_{3}(\%)=V_{\text {cmax }} /\left(6.25 V_{\text {cr }} \text { LMA } N_{\mathrm{m}}\right),
$$

where $V_{\text {cr }}$ is the specific activity of Rubisco (the maximum rate of RuBP carboxylation per unit Rubisco protein), and the coefficient of 6.25 [g (Rubisco) $\mathrm{g}^{-1}$ ( $\mathrm{N}$ in Rubisco)] converts $\mathrm{N}$ content to protein content. The value of $V_{\text {cr }}$ is 20.5 [ $\mu$ mol $\left(\mathrm{CO}_{2}\right) \mathrm{g}^{-1}$ (Rubisco) $\mathrm{s}^{-1}$ ] at $25^{\circ} \mathrm{C}$ for purified Rubisco enzyme from Spinacia oleracea (Jordan and Ogren 1984). This method is unable to determine the amount of inactivated Rubisco; the calculated value of $N_{3}$ is therefore an underestimate (Warren and Adams 2004). The remaining $\mathrm{N}$ corresponds to $\mathrm{N}_{4}$.

Statistical analysis: We used analysis of variance (ANOVA) to estimate the effects of $\mathrm{N}$ and of crown position, and of their interaction, on the physiological and growth properties of hybrid larch $\mathrm{F}_{1}$ seedlings. The tests were performed using SPSS 16.0 (SPSS Inc, USA) statistical software.

\section{Results}

Growth environment: The average height \pm SD in N0 plots was $341.96 \pm 86.96 \mathrm{~cm}$ and $353.82 \pm 64.63 \mathrm{~cm}$ in N50 plots, respectively. During the measuring period in mid-September 2010, the average values \pm SD of the PPF (6:00 $18: 00 \mathrm{~h}$ ) in the N0 and N50 plots were $144.0 \pm 60.8$ and $112.9 \pm 43.8\left[\mu \mathrm{mol} \mathrm{m}^{-2} \mathrm{~s}^{-1}\right.$ ] in the shade crown; and $324.5 \pm$ 106.8 and $320.3 \pm 121.0\left[\mu \mathrm{mol} \mathrm{m} \mathrm{m}^{-1}\right]$ in the sun crown, respectively. Light intensity in the shade crowns of the N0 plots and N50 plots was significantly lower than in the sun crowns $(P=0.05)$. No significant difference in the PPF was observed between the N0 and N50 plots $(P=0.159)$.

No significant difference was found in any soil parameters between the plots used for N0 and N50 before the N

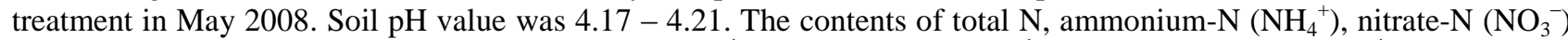
in the soil solution were respectively $3.05-3.08\left[\mathrm{~g} \mathrm{~kg}^{-1}\right], 3.44-4.11\left[\mathrm{mg} \mathrm{kg}^{-1}\right]$, and $9.37-10.0$ [mg kg-1 $]$. The average value of each parameter was calculated during the three years of the study from 2008 to 2010 . The content of $\mathrm{NO}_{3}^{-}$was significantly increased in $\mathrm{N} 50$ (34.76\% higher than N0), but the content of $\mathrm{NH}_{4}^{+}$did not change significantly. The contents of $\mathrm{Ca}$ and $\mathrm{Mg}$ in the soil solution were significantly greater in the N50 plot $(\mathrm{Ca}: 547.67 \mu \mathrm{M} ; \mathrm{Mg}: 83.21 \mu \mathrm{M})$ than in the N0 plot $(\mathrm{Ca}: 377.79 \mu \mathrm{M} ; \mathrm{Mg}: 55.09 \mu \mathrm{M})$. The content of $\mathrm{K}$ did not change significantly with N50 (N0, $113.01 \mu \mathrm{M} ; \mathrm{N} 50,116.08 \mu \mathrm{M})$.

Needle gas exchange: Values of $P_{\mathrm{Nmax}}$ and $g_{\mathrm{s}}$ did not change significantly in response to $\mathrm{N}$ application, or differ with canopy position. Values of $V_{\mathrm{cmax}}$ and $J_{\max }$ were significantly lower in the shade crown, and were unaffected by $\mathrm{N}$ application. PNUE in the shade crown was significantly higher than in the sun crown. $C_{\mathrm{i}}$ was significantly higher in the shade crown than in the sun crown. No significant interaction was found between $\mathrm{N}$ application and crown position for any parameter (Table 1). 
Needle nutrients, Chl content and LMA: $\mathrm{N}$ application did not significantly affect any parameters. The content of $\mathrm{N}$, $\mathrm{P}, \mathrm{K}$, chlorophyll in needles and LMA in the shade crown, were significantly lower than in the sun crown. No significant interaction was found between $\mathrm{N}$ application and crown position (i.e. shade- $v$ s. sun crown) for any parameter (Table 2).

Table 1. Photosynthetic capacity $( \pm \mathrm{SD})$ in needles located at upper crown $(\mathrm{U})$ and lower crown $(\mathrm{L})$ of hybrid larch $\mathrm{F}_{1}$ seedlings grown at two levels of $\mathrm{N}$ : $\mathrm{N} 0-0 \mathrm{~kg}(\mathrm{~N}) \mathrm{ha}^{-1} ; \mathrm{N} 50-50 \mathrm{~kg}(\mathrm{~N}) \mathrm{ha}^{-1} . V_{\mathrm{cmax}}-$ maximum rate of carboxylation, $J_{\max }-$ maximum rate of electron transport, $P_{\mathrm{Nmax}}-$ light-saturated net photosynthetic rate, $g_{\mathrm{s}}-$ stomatal conductance, $C_{\mathrm{i}}-$ intercellular $\mathrm{CO}_{2}$ concentration, PNUE - photosynthetic nitrogen-use efficiency. $n=8$. ANOVA: $*-P<0.05$; ** $-P<0.001 ;$ n.s. - not significant.

\begin{tabular}{|c|c|c|c|c|c|c|c|}
\hline & $\mathrm{N}$ level & $V_{\mathrm{cmax}}\left[\mu \mathrm{mol} \mathrm{m}{ }^{-2} \mathrm{~s}^{-1}\right]$ & $J_{\max }\left[\mu \mathrm{mol} \mathrm{m} \mathrm{s}^{-2}\right]$ & $P_{\mathrm{S}}\left[\mu \mathrm{mol} \mathrm{m} \mathrm{s}^{-2}\right]$ & $g_{\mathrm{s}}\left[\mathrm{mol} \mathrm{m}^{-2} \mathrm{~s}^{-1}\right]$ & $C_{\mathrm{i}}\left[\mu \mathrm{mol} \mathrm{mol}{ }^{-1}\right]$ & PNUE $\left[\mu \mathrm{mol} \mathrm{mol}{ }^{-1} \mathrm{~s}^{-1}\right]$ \\
\hline \multirow[t]{2}{*}{$\mathrm{U}$} & No & $110.87 \pm 14.84$ & $176.72 \pm 31.51$ & $9.28 \pm 2.08$ & $0.09 \pm 0.04$ & $188.20 \pm 28.90$ & $55.84 \pm 14.21$ \\
\hline & N50 & $112.91 \pm 41.18$ & $188.57 \pm 48.12$ & $9.36 \pm 2.54$ & $0.09 \pm 0.02$ & $201.48 \pm 63.20$ & $53.75 \pm 13.79$ \\
\hline \multirow[t]{2}{*}{$\mathrm{L}$} & NO & $90.14 \pm 18.23$ & $158.98 \pm 27.00$ & $9.94 \pm 1.91$ & $0.11 \pm 0.04$ & $220.55 \pm 50.03$ & $89.39 \pm 14.18$ \\
\hline & N50 & $64.88 \pm 9.86$ & $144.96 \pm 32.00$ & $7.88 \pm 2.23$ & $0.10 \pm 0.05$ & $233.94 \pm 34.36$ & $70.82 \pm 14.97$ \\
\hline \multicolumn{2}{|l|}{$\mathrm{N}$} & n.s. & n.s. & n.s. & n.s. & n.s. & $*$ \\
\hline \multicolumn{2}{|c|}{ Crown } & $* *$ & $*$ & n.s. & n.s. & $*$ & $* *$ \\
\hline \multicolumn{2}{|c|}{$\mathrm{N} \times$ Crown } & n.s. & n.s. & n.s. & n.s. & n.s. & n.s. \\
\hline
\end{tabular}

Table 2. Nutrient contents, chlorophyll (Chl) and leaf mass per area (LMA) \pm SD of needles located at upper crown (U) and lower crown (L) of hybrid larch seedlings grown at two levels of $\mathrm{N}$ : N0 $-0 \mathrm{~kg}(\mathrm{~N}) \mathrm{ha}^{-1} ; \mathrm{N} 50-50 \mathrm{~kg}(\mathrm{~N}) \mathrm{ha}^{-1}$. Ca - calcium; Chl chlorophyll; $\mathrm{K}$ - potassium; LMA - leaf mass per area; $\mathrm{N}$ - nitrogen; $\mathrm{Mg}$ - magnesium; $\mathrm{P}$ - phosphorus. $n=8$. ANOVA:* $-P<0.05$; $* *-P<0.001 ;$ n.s. - not significant.

\begin{tabular}{|c|c|c|c|c|c|c|c|c|}
\hline & $\mathrm{N}$ level & $\mathrm{N}\left[\mathrm{g} \mathrm{m}^{-2}\right]$ & $P\left[\mathrm{~g} \mathrm{~cm}^{-2}\right]$ & $\mathrm{K}\left[\mathrm{g} \mathrm{m}^{-2}\right]$ & $\mathrm{Ca}\left[\mathrm{g} \mathrm{m}^{-2}\right]$ & $\operatorname{Mg}\left[\mathrm{g} \mathrm{m}^{-2}\right]$ & Chl $\left[\mathrm{g} \mathrm{m}^{-2}\right]$ & LMA $\left[\mathrm{g} \mathrm{m}^{-2}\right]$ \\
\hline \multirow[t]{2}{*}{$\mathrm{U}$} & No & $2.37 \pm 0.31$ & $0.22 \pm 0.09$ & $0.81 \pm 0.14$ & $0.43 \pm 0.10$ & $0.11 \pm 0.04$ & $0.54 \pm 0.13$ & $104.38 \pm 9.70$ \\
\hline & N50 & $2.49 \pm 0.53$ & $0.19 \pm 0.06$ & $0.72 \pm 0.23$ & $0.41 \pm 0.09$ & $0.10 \pm 0.04$ & $0.60 \pm 0.24$ & $103.89 \pm 19.41$ \\
\hline \multirow[t]{2}{*}{$\mathrm{L}$} & No & $1.56 \pm 0.19$ & $0.18 \pm 0.06$ & $0.45 \pm 0.12$ & $0.35 \pm 0.10$ & $0.13 \pm 0.03$ & $0.41 \pm 0.05$ & $75.50 \pm 8.87$ \\
\hline & N50 & $1.56 \pm 0.26$ & $0.15 \pm 0.06$ & $0.40 \pm 0.13$ & $0.41 \pm 0.10$ & $0.12 \pm 0.02$ & $0.40 \pm 0.08$ & $76.59 \pm 12.37$ \\
\hline \multicolumn{2}{|l|}{$\mathrm{N}$} & n.s. & n.s. & n.s. & n.s. & n.s. & n.s. & n.s. \\
\hline \multirow{2}{*}{\multicolumn{2}{|c|}{$\begin{array}{l}\text { Crown } \\
\mathrm{N} \times \text { Crown }\end{array}$}} & $* *$ & $*$ & $* *$ & n.s. & n.s. & $*$ & $* *$ \\
\hline & & n.s. & n.s. & n.s. & n.s. & n.s. & n.s. & n.s. \\
\hline
\end{tabular}

Table 3. N allocation \pm SD to photosynthetic functions in needles located at upper crown (U) and lower crown (L) of the hybrid larch $\mathrm{F}_{1}$ grown under two levels of $\mathrm{N}$ : $\mathrm{N} 0-0 \mathrm{~kg}(\mathrm{~N}) \mathrm{ha}^{-1} ; \mathrm{N} 50-50 \mathrm{~kg}(\mathrm{~N}) \mathrm{ha}^{-1}$. Photosynthetic functions are categorized as lightharvesting complex protein (LHCP) and photosystems $\left(N_{1}\right)$, bioenergetics (electron carriers except for photosystems, coupling factor and Calvin cycle enzymes except for Rubisco $\left(N_{2}\right)$, Rubisco $\left(N_{3}\right)$ and other $\left(N_{4}\right) . n=8$. ANOVA: * $-P<0.05$; n.s. - not significant.

\begin{tabular}{|c|c|c|c|c|c|}
\hline & $\mathrm{N}$ level & $N_{1}[\%]$ & $N_{2}[\%]$ & $N_{3}[\%]$ & $N_{4}[\%]$ \\
\hline \multirow[t]{2}{*}{$\mathrm{U}$} & No & $25.00 \pm 2.74$ & $5.16 \pm 1.41$ & $36.74 \pm 6.60$ & $43.40 \pm 8.20$ \\
\hline & N50 & $16.01 \pm 5.80$ & $5.28 \pm 1.58$ & $36.43 \pm 14.65$ & $42.28 \pm 20.00$ \\
\hline \multirow[t]{2}{*}{$\mathrm{L}$} & No & $16.55 \pm 4.77$ & $6.89 \pm 1.01$ & $43.92 \pm 14.26$ & $30.34 \pm 13.70$ \\
\hline & N50 & $16.72 \pm 3.22$ & $6.35 \pm 1.29$ & $33.00 \pm 7.78$ & $43.93 \pm 10.03$ \\
\hline \multicolumn{2}{|l|}{$\mathrm{N}$} & n.s. & n.s. & n.s. & n.s. \\
\hline \multicolumn{2}{|c|}{ Crown } & n.s. & $*$ & n.s. & n.s. \\
\hline \multicolumn{2}{|c|}{$\mathrm{N} \times$ Crown } & n.s. & n.s. & n.s. & n.s. \\
\hline
\end{tabular}

$\mathrm{N}$ allocation in the photosynthetic system: There was no significant effect of $\mathrm{N}$ application or of canopy position on $\mathrm{N}$ allocation to $N_{1}$ and $N_{3}$ (Table 3). N allocation to $N_{2}$ was significantly greater in the shade- than in the sun crown. There was no significant interaction between $\mathrm{N}$ application and crown position for any parameter.

\section{Discussion}

Low values of $P_{\mathrm{Nmax}}$ in shade crown were correlated with low foliar N concentration, and high $P_{\mathrm{Nmax}}$ was correlated with high foliar $\mathrm{N}$ concentration (Table 2). It is possible that there was no photoinhibition of photosynthesis in the shade crown in our study (Baker and Bowyer 1994). Field (1983) proposed that canopy photosynthesis is maximized when sunlit leaves have greater $\mathrm{N}$ content than shaded leaves. Our data are therefore consistent with previous observations of 
herbaceous and woody plants (Fife et al. 1997, Wilson et al. 2000, Warren et al. 2003, Posch et al. 2008, Johnson et al. 2010). Our results did not, however, confirm that $P_{\mathrm{Nmax}}$ is greater in the sun crown irrespective of foliar N. In fact a higher $V_{\mathrm{cmax}}$ and $J_{\max }$, as well as higher $\mathrm{N}$ content, were observed in the sun crown.

The value of $C_{\mathrm{i}}$ was higher in the shade crown than in the sun crown (Table 1). Greater $C_{\mathrm{i}}$ does not necessarily induce a difference in $P_{\mathrm{Nmax}}$ between the shade and sun crowns, although $V_{\mathrm{cmax}}$ and $J_{\max }$ were lower in the shade crown than in the sun crown, and PNUE was higher in the shade crown. The value of $C_{\mathrm{i}}$ is the result of a balance between the supply of $\mathrm{CO}_{2}$ from the atmosphere, through the stomata, and $\mathrm{CO}_{2}$ demand in chloroplasts (Lambers et al. 2008). The reductions in $V_{\text {cmax }}$ and $J_{\max }$ induce an increase in $C_{\mathrm{i}}$. The plant then usually closes stomata to prevent loss of water by transpiration. It might not be necessary for needles in the shade canopy to close their stomata completely, however, because of the lower temperature in the shade crown than in the sun crown; also, there is only a small hydraulic limitation (Kupper et al. 2006), and the needles may be young (Escudero and Mediavilla 2003). In fact we found that $g_{\mathrm{s}}$ in the shade crown was higher in the shade crown than in the sun crown, not lower.

The change in $\mathrm{N}$ allocation to photosynthesis may partly compensate for the decrease in photosynthetic activity due to the increase in PNUE of the needles in the shade crown. The $\mathrm{N}$ allocation to $N_{2}$, which is related mainly to the function of RuBP regeneration, was significantly higher in the shade crown (Table 3). This implies in turn that shade crown needles increased their bioenergetic transport efficiency. An increase in $\mathrm{N}$ allocation to $N_{1}$ might also increase photosynthetic activity by exploiting more light energy for photosynthesis (Kitaoka and Koike 2004, Kitaoka et al. 2009). Our results showed, however, that $\mathrm{N}$ allocation to $N_{1}$ was not significantly enhanced in the shade crown (Table 3 ). Based on this study, we suggest that $14.69-16.72 \% \mathrm{~N}$ was allocated to $N_{1}$. This is an optimal ratio that allows for adequate light energy for photosynthesis, even in the shade crown.

Foliar nutrients other than $\mathrm{N}$ may also be important in the assimilation of carbon by plants. Foliar $\mathrm{N}, \mathrm{P}$ and $\mathrm{K}$ were significantly less in the shade crown than in the sun crown, and foliar $\mathrm{Ca}$ and $\mathrm{Mg}$ did not differ significantly between the sun and shade crowns (Table 2). These reductions in N, P, and K contents were due mainly to the decrease in LMA, rather than the decrease in mass-based contents (data not shown). The mass-based needle $\mathrm{Ca}$ and $\mathrm{Mg}$ contents were higher in the shade crown than the sun crown. This enhancement of the $\mathrm{Ca}$ and $\mathrm{Mg}$ contents may be important for acclimation to low light conditions.

In conclusion, allocation of $\mathrm{N}$ within the canopy of the hybrid larch $\mathrm{F}_{1}$ was significantly influenced by the irradiation conditions. Indeed, $\mathrm{N}$ allocation within needles of the hybrid larch changed with the light conditions; more foliar $\mathrm{N}$ was reallocated to bioenergetics transport apparatus in photosynthetic systems. However, $\mathrm{N}$ application did not increase net photosynthesis.

\section{References}

Anten, N.P.R., During, H.J.: Is analyzing the nitrogen use at the plant canopy level a matter of choosing the right optimization criterion? - Oecologia 167: 293-303, 2011.

Baker, N.R., Bowyer, J.R.: Photoinhibition of photosynthesis. -In: Baker, N.R., Bowyer, J.R.: Photoinhibition of Photosynthesis from Molecular Mechanisms to the Field. Pp. 1-19. BIOS Scientific Publishers, Oxford 1994.

Barnes, J.D., Balaguer, L., Manrique, E., Elvira, S., Davison, A.W.: A reappraisal of the use of DMSO for the extraction and determination of chlorophylls $a$ and $b$ in lichens and higher plants. - Environ. Exp. Bot. 32: 85-100, 1992.

Bernacchi, C.J., Singsaas, E.L., Pimentel, C., Portis, A.R., Long, S.P.: Improved temperature response functions for models of Rubisco-limited photosynthesis. - Plant Cell Environ. 24: 253-259, 2001.

Braun, S., Thomas, V.F.D., Quiring, R., Flückiger, W.: Does nitrogen deposition increase forest production? The role of phosphorus. - Environ. Pollut. 158: 2043-2052, 2010.

DeJong, T.M., Day, K.R., Johnson, R.S.: Partitioning of leaf nitrogen with respect to within canopy light exposure and nitrogen availability in peach (Prunus persica). - Trees. 3: 89-95, 1989.

Escudero, A., Mediavilla, S.: Decline in photosynthetic nitrogen use efficiency with leaf age and nitrogen resorption as determinants of leaf life span. - J. Ecol. 91: 880-889, 2003.

Farquhar, G.D., von Caemmerer, S., Berry, J.A.: A biochemical model of photosynthetic $\mathrm{CO}_{2}$ assimilation in leaves of $\mathrm{C}_{3}$ species. Planta 149: 78-90, 1980.

Field, C.: Allocating leaf nitrogen for the maximization of carbon gain: leaf age as a control on the allocation program. - Oecologia 56: 341-347, 1983.

Fife, D.N., Nambiar, E.K.S.: Changes in the canopy and growth of Pinus radiata in response to nitrogen supply. - Forest Ecol. Manage. 93: 137-152, 1997.

Galloway, J.N., Dentener, F.J., Capone, D.G.et al.: Nitrogen cycles: past, present and future. - Biogeochemistry 70: 153-226, 2004.

Hirose, T., Werger, M.J.A.: Maximizing daily canopy photosynthesis with respectto the leaf nitrogen allocation pattern in the canopy. - Oecologia 72: 520-526, 1987.

Hirose, T., Werger, M.J.A., Pons, T.L., Rheenen van, J.W.A.: Canopy structure and leaf nitrogen distribution in a standof Lysimachia vulgaris L. as influenced by stand density. -Oecologia 77: 145-150, 1988.

Japan Meteorological Agency: Statistical Information of Meteorology. http://www.jma.go.jp/jma/menu/report.html, 2012. [In Jap.] 
Jordan, D.B., Ogren, W.L.: The $\mathrm{CO}_{2} / \mathrm{O}_{2}$ specificity of ribulose 1,5-bisphosphate carboxylase/oxygenase. Dependence on ribulosebisphosphate concentration, $\mathrm{pH}$ and temperature. -Planta 161: 308-313, 1984.

Johnson, I.R., Thornley, J.H.M., Frantz, J.M., Bugbee, B.: A model of canopy photosynthesis incorporating protein distribution through the canopy and its acclimation to light, temperature and $\mathrm{CO}_{2}$. - Ann. Bot. 106: 735-749, 2010.

Kayama, M., Makoto, K., Nomura, M., Satoh, F., Koike, T.: Dynamics of elements in larch seedlings (Larix kaempferi) regenerated on serpentine soil in northern Japan. - Landscape Ecol. Eng. 5: 125-135, 2009.

Kimura, S. D., Saito, M., Hara, H., Xu, Y.H., Okazaki, M .: Comparison of nitrogen dry deposition on cedar and oak leaves in the Tama Hills using foliar rinsing method. - Water Air Soil Pollut. 202: 369-377, 2009.

Kitaoka, S., Mori, S., Matsuura, Y., Abaimov, A.P., Sugishita, Y., Satoh, F., Sasa, K. and Koike, T.: Comparison between the photosynthetic characteristics of larch species grown in northern Japan and central Siberia. - Proc. Joint Siberia Permafrost Studies 8: 49-54, 2000.

Kitaoka, S., Koike, T.: Invasion of broadleaf tree species into a larch plantation: Seasonal light environment, photosynthesis, and nitrogen allocation. - Physiol. Plant. 121: 604-611, 2004.

Kitaoka, S., Watanabe, Y., Koike, T.: The effects of cleared larch canopy and nitrogen supply on gas exchange and leaf traits in deciduous broad-leafed tree seedlings. - Tree Physiol. 29: 1503-1511, 2009.

Koike, T.: A trial of revegetation practices with larch species under changing environment. - Landscape Ecol. Eng. 5: 97-98, 2009.

Koike, T., Yazaki, K., Funada, R., Maruyama, Y., Mori, S., Sasa, K.: Forest health and vitality in northern Japan. A history of larch plantation. - Res. Notes Fac. Forestry, The Univ. Joensuu 92: 49-60, 2000.

Kupper, P., Sellin, A., Tenhunen, J., Schmidt, M., Rahi, M.: Effects of branch position on water relations and gas exchange of European larch trees in an alpine community. - Trees. 20: 265-272, 2006.

Kuuluvainen, T., Pukkala, T.: Simulation of within-tree and between-tree shading of direct radiation in a forest canopy: effect of crown shape and sun elevation. - Ecol. Model. 49: 89-100, 1989.

Lambers, H., Chapin, F.S., III, Pons, T.L.: Plant physiological ecology. Springer Science+Bussiness Media LIC, New York 2008.

Long, S.P., Bernacchi, C.J.: Gas exchange measurements, what can they tell us about the underlying limitations to photosynthesis? Procedures and sources of error. - J. Exp. Bot. 54: 2393-2401, 2003.

Magnani, F., Mencuccini, M., Borghetti, M., et al.: The human footprint in the carbon cycle of temperate and boreal forests. - Nature 447: 848-850, 2007.

Marek, M.V., Urban, O., Šprtová, M., Pokorný, R., Rosová, Z., Kulhavý, J.: Photosynthetic assimilation of sun versus shade Norway spruce [Picea abies (L.) Karst] needles under the long-term impact of elevated $\mathrm{CO}_{2}$ concentration. - Photosynthetica 40: 259-267, 2002.

Matyssek, R., Fromm, J., Rennenberg, H., Roloff, A.: Biologie der Bäume. Eugen Ulmera Kg, Stuttgart 2008. [In Germ.]

Nakaji, T., Takenaga, S., Kuroh, M., Izuta, T.: Photosynthetic response of Pinus densiflora seedlings to high nitrogen load. -Environ. Sci. 9: 269-282, 2002.

Niinemets, Ü.: Distribution patterns of foliar carbon and nitrogen as affected by tree dimensions and relative light conditions in the canopy of Picea abies. - Trees 11: 144-154, 1997.

Niinemets, Ü., Tenhunen, J.D.: A model separating leaf structural and physiological effects on carbon gain along light gradients for the shade tolerant species Acer saccharum. - Plant Cell Environ. 20: 545-566, 1997.

Niinemets, Ü., Tenhunen, J.D., Canta, N.R., Chavis, M.M., Faria, T., Pereira, J.S., Reynolds, J.F.: Interactive effects of nitrogen and phosphorus on the acclimation potential of foliage photosynthetic properties of cork oak, Quercus suber, to elevated atmospheric $\mathrm{CO}_{2}$ concentrations. - Global Change Biol. 5: 455-470, 1999.

Posch, S., Warren, C.R., Kruse, J., Guttenberger, H., Adams, M.A.: Nitrogen allocation and the fate of absorbed light in 21-year-old Pinus radiata. - Tree Physiol. 28: 375-384, 2008.

Qu, L.Y., Shinano, T., Quoreshi, A.M., Tamai, Y., Osaki, M., Koike, T.: Allocation of ${ }^{14}$ C-Carbon in two species of larch seedlings infected with ectomycorrhizal fungi. - Tree Physiol. 24: 1369-1376, 2004.

Rosati, A., Day, K.R., DeJong, T. M.: Distribution of leaf mass per unit area and leaf nitrogen concentrationdetermine partitioning of leaf nitrogen within tree canopies. -Tree Physiol. 20: 271- 276, 2000.

Ryu, K., Watanabe, M., Shibata, H., Takagi, K., Nomura, M., Koike, T.: Ecophysiological responses of the larch species in northern Japan to environmental changes as a base of afforestation. - Landscape Ecol. Eng. 5: 99-106, 2009.

Schulze, E-D., Beck, E., Müller-Hohenstein, E.: Plant ecology. Springer, Berlin - Heidelberg, 2005.

Šesták, Z.(ed.): Photosynthesis during Leaf Development. -Academia Praha, Dr. W. Junk Publ., Dordrecht Boston Lancaster 1985.

Shinano, T., Lei, T.T., Kawamukai, T., Inoue, M.T., Koike, T., Tadano, T.: Dimethylsulfoxide method for the extraction of chlorophylls a and b from the leaves of wheat, field bean, dwarf bamboo, and oak. - Photosynthetica 32: 409-415, 1996.

Takashima, T., Hikosaka, K., Hirose, T.: Photosynthesis or persistence: nitrogen allocation in leaves of evergreen and deciduous Quercus species. - Plant Cell Environ. 27: 1047-1054, 2004.

Tissue, D.T., Lewis, J.D.: Photosynthetic responses of cottonwood seedlings grown in glacial through future atmospheric $\left[\mathrm{CO}_{2}\right]$ vary with phosphorus supply. - Tree Physiol. 30: 1361-1372, 2010.

Warren, C.R., Adams, M.A.: Evergreen trees do not maximize instantaneous photosynthesis. - Trend Plant Sci. 9: 270-274, 2004.

Warren, C.R., Ethier, G.J., Livingston, N.J. et al.: Transfer conductance in second growth Douglas-fir (Pseudotsuga menziesii (Mirb.) Franco) canopies. - Plant Cell Environ. 26: 1215-1227, 2003.

Wilson, K.B., Baldocchi, D.D., Hanson, P.J.: Spatial and seasonal variability of photosynthetic parameters and their relationship to leaf nitrogen in a deciduous forest. - Tree Physiol. 20: 565-575, 2000. 